\section{International Scientific Journal Theoretical \& Applied Science}

\author{
p-ISSN: 2308-4944 (print) e-ISSN: 2409-0085 (online) \\ Year: $2016 \quad$ Issue: 8 Volume: 40 \\ Published: $30.08 .2016 \quad \underline{\text { http://T-Science.org }}$
}

SECTION 9. Chemistry and chemical technology.
F.Y. Aliyev

Academician, doctor of chemical sciences, professor Ganja branch of Azerbaijan National Academy of

Sciences,

ameagb@hotmail.com

M.T. Sharifova

Institute of Ecology and Natural Resources Ganja branch of Azerbaijan National Academy of

Sciences,

Ch.G. Ismailov

Institute of Ecology and Natural Resources Ganja branch of Azerbaijan National Academy of

Sciences,

B.A. Budagli

Azerbaijan Technology University,

A.T. Mammadova

Ganja State University

\title{
COMBINED METHOD FOR PROCESSING HYDROCHEMICAL ALUNITE OF ZAYLIK ORE DEPOSITS
}

\footnotetext{
Abstract: Article is devoted to the new combined method for processing of alunite ore. The basis of the previous project restoration and alkaline scheme has been laid, which error led to the freezing of the activities of the Ganja Alumina Plant. Proof of this are:

1. Compensation for the loss of alkali was carried out by sintering aluminum hydroxide with potassium and sodium sulfates in the presence of coke, resulting in an increased loss of alumina and alkali.

2. Formation of gas after sintering low-SO $\mathrm{S}_{2}$, polluting air pool.

3. Significant dust removal from the fluidized bed roasting furnaces and recovery.

The main advantages of the new method of processing of alunite ore:

Firing and recovery milled alunite ore, sulfuric acid production;

Alunite air pollution by dust and sulfur dioxide;

Provisioning of high chemical extraction of useful components.

Key words: bauxite, alunite, hydro-chemical method, ore processing.

Language: English

Citation: Aliyev FY, Sharifova MT, Ismailov CG, Budagli BA, Mammadova AT (2016) COMBINED METHOD FOR PROCESSING HYDROCHEMICAL ALUNITE OF ZAYLIK ORE DEPOSITS. ISJ Theoretical \& Applied Science, 08 (40): 19-22.

Soi: http://s-o-i.org/1.1/TAS-08-40-4 Doi: crossef http://dx.doi.org/10.15863/TAS.2016.08.40.4
}

\section{Introduction}

World production of aluminum is mainly based on bauxite. However, in view of limited reserves of bauxite compared with the growth dynamics of the production of aluminum, as well as the uneven distribution of their fields, are becoming increasingly important different types of raw materials.

In particular, Azerbaijan and other countries is crucial industrial development of methods of complex processing of alunite ores. In recent years the search is on for recycling methods alunite in countries such as China, Mexico, Iran, Japan, Italy, and others [1].

The project is complex processing Zaylikalunite at Ganja Alumina Plant laid restoration and alkaline scheme proposed senior researcher of Russian National Aluminium-Magnesium Institute) Labutin GV [2].Assuming pure alunite, chemical formula of which can be represented as:

$$
\begin{gathered}
(\mathrm{K}, \mathrm{Na})_{2} \mathrm{SO}_{4} \bullet \mathrm{Al}_{2}\left(\mathrm{SO}_{4}\right)_{3} \bullet 2 \mathrm{Al}_{2} \mathrm{O}_{3} \bullet 6 \mathrm{H}_{2} \mathrm{O} \text { or } \\
(\mathrm{K}, \mathrm{Na})_{2} \mathrm{SO}_{4} \bullet \mathrm{Al}_{2}\left(\mathrm{SO}_{4}\right)_{3} \bullet 4 \mathrm{AL}(\mathrm{OH})_{3},
\end{gathered}
$$

then the percentage of individual components is expressed by the following data [1]:

$$
\mathrm{Al}_{2} \mathrm{O}_{3}-37 \%, \mathrm{~K}_{2} \mathrm{O}-11,4 \%, \mathrm{SO}_{3}-38,6 \% \mathrm{uH}_{2} \mathrm{O}-13 \%
$$

potassium oxide, part of alunite, usually replaced by $\mathrm{Na}_{2} \mathrm{O}$. 


\begin{tabular}{|c|c|c|c|c|c|c|}
\hline Impact Factor: & $\begin{array}{l}\text { ISRA (India) } \\
\text { ISI (Dubai, UAE } \\
\text { GIF (Australia) } \\
\text { JIF }\end{array}$ & $\begin{array}{l}=1.344 \\
=0.829 \\
=0.564 \\
=1.500\end{array}$ & $\begin{array}{l}\text { SIS (USA) } \\
\text { PИНЦ (Russia } \\
\text { ESJI (KZ) } \\
\text { SJIF (Morocco }\end{array}$ & $\begin{array}{l}=0.912 \\
=0.234 \\
=1.042 \\
=2.031\end{array}$ & $\begin{array}{l}\text { ICV (Poland) } \\
\text { PIF (India) } \\
\text { IBI (India) }\end{array}$ & $\begin{array}{l}=6.630 \\
=1.940 \\
=4.260\end{array}$ \\
\hline
\end{tabular}

Average chemical composition of alunite ore Zaylik (weight\%).

Table 1

\begin{tabular}{|c|c|c|c|c|c|c|c|c|c|}
\hline $\begin{array}{c}\mathrm{Al}_{2} \mathrm{O}_{3} \\
\text { al. }\end{array}$ & $\begin{array}{c}\mathrm{Al}_{2} \mathrm{O}_{3} \\
\text { unal. }\end{array}$ & $\mathrm{SO}_{3}$ & $\mathrm{Na}_{2} \mathrm{O}$ & $\mathrm{K}_{2} \mathrm{O}$ & $\mathrm{SiO}_{2}$ & $\mathrm{Fe}_{2} \mathrm{O}_{3}$ & $\mathrm{H}_{2} \mathrm{O}$ & $\mathrm{V}_{2} \mathrm{O}_{5}$ & others \\
\hline 19,1 & 2,5 & 20,0 & 1,43 & 3,72 & 41,4 & 3,6 & 6,75 & 0,05 & 1,45 \\
\hline
\end{tabular}

\section{Materials and methods}

The reductive-base method of processing alunite ores at GGC, along with advantages, also has significant drawbacks, which together with errors laid down in the draft, hampered the development of the plant design capacity and led to loss of production. Works remedial design technology and hardware-technological scheme of GGC have not led to the desired results. Currently excluded from the manufacturing technology process stages firing and recovery, as well as a workshop for the production of sulfuric acid, ire, in fact the plant is frozen and cannot work on the restoration and alkaline fashion. New ways of processing alunite ore was necessary to develop for the future of the plant.

In currently experiencing several such methods are of practical value in the literature:

-technology two-step processing of alunite GV Labutin [4];

- alunite ore processing method (method-YOU Nasyrov) [3];

-potashno alkaline alunite ore processing method (method-Liner Tagiyev) [1].

The proposed new ways of processing of alunite ores, along with advantages, also have several drawbacks, chief among which is to invest in the production of additional capital. With regard to the conditions of the factory, in our view, acceptable we proposed a combined hydro-chemical method of processing of alunite ore, combining a two-step processing of alunite and production of potash lye for the conversion of potassium sulfate and sodium diaphragm electrolysis of potassium chloride

solution. Technological scheme of this method is presented on figure.

The essence of our proposed method hydrochemical processing Zaylik alunite deposits is as follows (scheme). Alunite ore after crushing, dry milling is transported into the hopper for the first leaching.

Leaching can be carried out in an open mixer of the pulp and if the temperature is maintained within $100 \mathrm{~S}^{0}$, the duration required for virtually complete extraction of $\mathrm{Al}_{2} \mathrm{O}_{3}$ is 1 hour. 1st leaching takes place according to the following reaction:

$$
\begin{aligned}
& \left(\mathrm{K}, \mathrm{Na}_{2} \mathrm{SO}_{4} \bullet \mathrm{Al}_{2}\left(\mathrm{SO}_{4}\right)_{3} \bullet 4 \mathrm{Al}(\mathrm{OH})_{3}+\mathrm{P.P} .+6 \mathrm{KOH}=\right. \\
& \left(\mathrm{K}, \mathrm{Na}_{2} \mathrm{SO}_{4}+3 \mathrm{~K}_{2} \mathrm{SO}_{4}+6 \mathrm{Al}(\mathrm{OH})_{3}+\mathrm{P} . \mathrm{P} .\right. \\
& \text { SolutionSolidphase }
\end{aligned}
$$

In accordance with this reaction sulphates into solution and the aluminum hydroxide remains in solid phase, together with the remaining barren rock.

The resultant slurry after the first leach to existing technology GGC hydro separator is divided into at sand (48\%) and silts (52\%) fractions.

Pulp fraction is filtered and washed on a rotary filter. It can be used to produce building materials or for foundry molding.

The pulp slurry from the clay fraction and aluminum hydrate (concentrate) to maintain and washed in 5 chamber thickeners. The washed underflow concentrate is fed to the second leaching circulating aluminate solution and further processed by Bayer system.

2nd leaching takes place by the following reactions:

$$
\begin{gathered}
6 \mathrm{Al}(\mathrm{OH})_{3}+\mathrm{PP} .+6 \mathrm{NaOH}=3\left(\mathrm{Na}_{2} \mathrm{O} \cdot \mathrm{Al}_{2} \mathrm{O}_{3}\right)+\mathrm{PP} .+12 \mathrm{H}_{2} \mathrm{O} \\
\mathrm{SiO}_{2}+2 \mathrm{NaOH}=\mathrm{Na}_{2} \mathrm{O} \cdot \mathrm{SiO}_{2}+\mathrm{H}_{2} \mathrm{O}
\end{gathered}
$$

After concentrating and washing the insoluble residue from the 2 nd leaching the resulting to slurry ejected field.

Draining from the second leaching is fed. This also served as seed white slurry SJ: $\mathrm{m}=2.5: 3.0$.
Process occurs at mixers $90 \mathrm{~S}^{0}$ temperature and seeded $30-40 \mathrm{~g} / 1$ solids, delayed at least 6 hours. Heating is provided by a hollow steam coils.

Desiliconization passes through the following reaction:

$$
\mathrm{Na}_{2} \mathrm{O} \bullet \mathrm{Al}_{2} \mathrm{O}_{3}+2 \mathrm{Na}_{2} \mathrm{O} \cdot \mathrm{SiO}_{2}+4 \mathrm{H}_{2} \mathrm{O}=\mathrm{Na}_{2} \mathrm{O} \bullet \mathrm{Al}_{2} \mathrm{O}_{3} \cdot \mathrm{SiO}_{2} \cdot 2 \mathrm{H}_{2} \mathrm{O}+4 \mathrm{NaOH}
$$

The pulp after condenses a 2-tiered thickeners. Draining 2 longline thickeners supplied to the control filter (LVANZH-25), and from white slurry thickeners cones (tv 300-400 g / 1 ) is fed. Chats white slurry fed to the seed and the rest is filtered and washed on the filter-Press. The washed white slurry was repulsed with water and fed to the production of a coagulant for water purification [1]. 


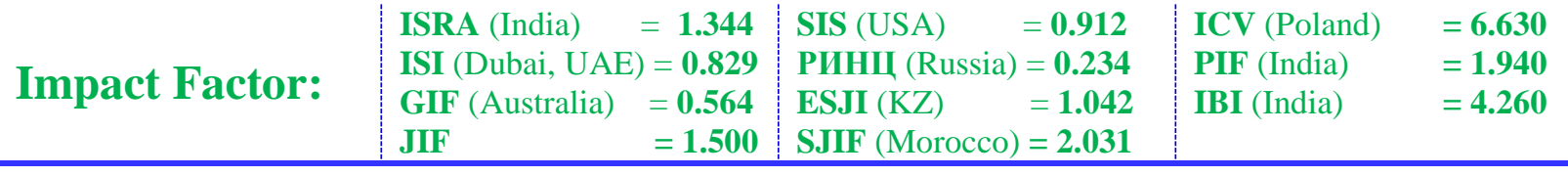

After the desilication aluminate solution fed to the decomposition

$$
\mathrm{NaAlO}_{2}+2 \mathrm{H}_{2} \mathrm{O}=\mathrm{Al}(\mathrm{OH})_{3+} \mathrm{NaOH}
$$

The diluted aluminate solution $\mathrm{Na}_{2} \mathrm{O}_{\mathrm{k}}=150 \mathrm{~g} /$ $\mathrm{L} ; \alpha \mathrm{k}=1.8-2.0$, a solids content of not more than $0.015 \mathrm{~g} / \mathrm{L}$, with a temperature of $70-75 \mathrm{~S}^{0}$ to $60 \mathrm{~S}^{0}$ is cooled and fed to the main decomposers. There also comes a seed hydrate. The duration of the decomposition process of about 70 hours.Cooling temperature $40-45 \mathrm{~S}^{0}$, twisting depth of $-50 \%$. Pulp hydroxide in a three-tiered thickeners.

Draining with thickeners (milky solution) was filtered on a 125-LVANZH filters. The mother liquor is fed, and then as a working solution is fed to the second leaching. Production hydrate subjected to a 3fold for the countercurrent washing circuit on vacuum drum filters BOU-20 and by means of the belt conveyor is sent to calcification. The moisture content in the productive hydrate should not exceed $12 \%$ and not laundered alkali- $0.04 \%$.

After the mother liquor, vanadium sludge is extracted from it.

Calcination of aluminum hydroxide is conducted to dehydration and getting out of it is practically non-hygroscopic alumina.

The filtrate from the rotary filter of drain and thickeners derived from 1-govyschelachivaniya as potassium and sodium sulphate solution is fed to give potassium sulfate. Potassium sulfate is stored and sent as mineral fertilizer. The sodium sulfate mother liquor is supplied to the conversion:

$$
\mathrm{Na}_{2} \mathrm{SO}_{4}+2 \mathrm{KOH}=\mathrm{K}_{2} \mathrm{SO}_{4}+2 \mathrm{NaOH}
$$

Resulting from the conversion of the alkali is to fill the loss of alkali.

In our proposed method for processing hydrochemicalalunite ore in the first leaching stage, as well as the conversion of $\mathrm{KOH}$ required $\mathrm{Na}_{2} \mathrm{SO}_{4}$.

The main advantages of the new method of processing of alunite ore:

-Significant simplify hardware-technological scheme. Excluded are the most energy-intensive and complex operation processes (roasting and restoration milled alunite ore, sulfuric acid production, sintering);

-air pollution alunite dust and sulfur dioxide;

-Provides high chemical extraction of useful components from ores;

-no need for fine grinding rock (grinding to 40$50 \mathrm{~m}$. sufficient to substantially complete decomposition of alunite);

-the possibility of rapid leaching "concentrate" in open agitators with high extraction of alumina;

$\mathrm{SO}_{3}$ aluminum sulfate derived from the Bayer process technology that allows you to work with concentrated aluminate solution [1].

\section{Results and conclusion}

Besides these advantages our proposed method has its drawbacks, the main ones are:

1. The need to use a very dilute alkaline solution for the 1st leaching alunitbreed. When the caustic concentration above $10 \%$ is already obtained solutions, close to saturation sulfates. With further increase in the concentration of caustic alkali is saturated solutions of sulphates and slight fluctuation in temperature can cause them to crystallization in the mixer settlers, communications, pumps, etc. In a production environment it may stop process;

2. The first leaching still remains in solution for a number of aluminum oxide, which reduces the degree of extraction of alumina.

However, despite these drawbacks, the advantages of the proposed method of contact, as compared to other, obvious.

The basis of the previous project restoration and alkaline scheme has been laid, which error led to the freezing of the activities of the Ganja Alumina Plant. Proof of this are:

A) Compensation for the loss of alkali was carried out by sintering aluminum hydroxide with potassium and sodium sulfates in the presence of coke, resulting in an increased loss of alumina and alkali.

B) Formation of gas after sintering low- $\mathrm{SO}_{2}$, polluting air pool.

C) Significant dust removal from the fluidized bed roasting furnaces and recovery.

\section{References:}

1. Tagiev EI (2006) «Tekhnologiya kompleksnoy bezotkhodnoy pererabotki alunitovykh rud», Baku, Elm, pp. 37-38 (504 p.)

2. Labutin GV (1965) «Alunity», pp. 66-86 (99 p.)

3. Nasyrov GZ (1967) «Puti usovershenstvovaniya tekhnologicheskoy skhemy KIRAZa»
Dissertatsiya na soiskanie uchenoy stepeni k.t.n., pp. 102.

4. Labutin GV, Labutin SV «Sposob pererabotki alunita (dvukhstadiynyy)». Avt.svid. SSSR №42065. ot 07.07.1934. 


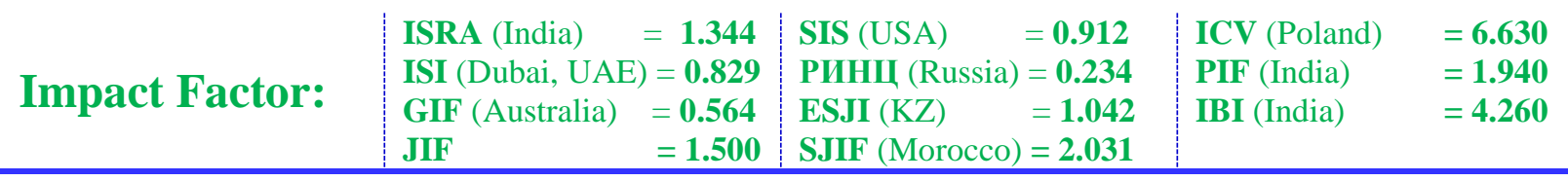

5. Layner AI (1961) «Proizvodstvo glinozema».Moskva,Izd. Metallurgiya. 619 p.

6. Abbasov IM, Sharifova MT, Nagiev NG (2007) Issledovanie nekotorykh svoystv ilovoy fraktsii shlamovykh otkhodov glinozemnogo proizvodstva. Sb. Izvestiy Gyandzhinskogo otdeleniya NANA, Gyandzha «Elm», №27, pp. 19.

7. Abbasov IM, Sharifova MT, Nagiev NG, Imanova OM, Sadygova UE (2008) Poluchenie kompozitsiy s ispol'zovaniem otkhodov glinozemnogo proizvodstva. Sb. Izvestiy Gyandzhinskogo otdeleniya NANA, Gyandzha «Elm», №33, pp.89.
8. Sharifova MT, Ismailov CG, Il'yasova AK (2012) Issledovanie fiziko-mekhanicheskikh i khimicheskikh svoystv promyshlennykh otkhodov alunitovogo proizvodstva kak napolniteley peschanogo asfal't-betona. Sb. Izvestiy Gyandzhinskogo otdeleniya NANA, Gyandzha «Elm», №49, pp.18.

9. Robert M. Jones (1999) Mechanics of Composite Materials (2nd ed.). Taylor \& Francis. ISBN 9781560327127

10. Autar K. Kaw (2005) Mechanics of Composite Materials (2nd ed.). CRC. ISBN 0-8493-1343-0 